\title{
The Program and Activities of the National Catholic Welfare Council
}

\author{
By Rev. R. A. McGowan \\ Assistant Director, Social Action Department, National Catholic Welfare Council
}

$\mathrm{T}$ HE labor program of the National Catholic Welfare Council is based upon the Program of Social Reconstruction, which was issued by the bishops who administered the National Catholic War Council, and upon the section entitled Industrial Relations in the Pastoral Letter of the American Hierarchy. The first of these is the more famous and has come to be known as the Bishops' Program. The Pastoral Letter contains fewer details than the Bishops' Program, but the salient principles of both are the same.

\section{WAGES}

Both insist upon the family living wage which includes, according to the Pastoral Letter, "not merely decent maintenance for the present, but also a reasonable provision for such future needs as sickness, invalidity and old age." 'The Bishops' Program says that "the laborers' right to a living wage is the first moral charge upon industry," and that while the employer has a right to get a reasonable living out of his business, "he has no right to interest until his employees have obtained at least living wages." The Bishops' Program emphasizes that this is only the minimum of justice. It urges that the general level of wages reached at the end of the War should not be lowered; first, because before the War a considerable majority were not making living wages; second, because wages did not increase faster than the cost of living; third, because a living wage is not the full measure of justice; and fourth, because it is economically sounder and humanly fairer to pay better than living wages in a country as rich as ours.

As regards women workers, the Bishops' Program says that "those women who are engaged at the same tasks as men should receive equal pay for equal amounts and qualities of work." It adds that the proportion of women in industry should be reduced to the smallest practicable limits.

\section{UnIONS}

The Pastoral Letter reaffirms "the right of the workers to form and maintain the kind of organization that is necessary and that will be most effectual in serving their welfare." The slightly but not materially changed form found in the Summary of the Bishops' Program expresses the hope "that the right of labor to organize and deal with employers through chosen representatives will never again be called into question by any considerable number of employers." Labor unions, according to the Pastoral Letter, have been and still are "necessary in the struggle of the workers for fair wages and fair conditions of employment."

\section{Conciliation and Arbitration}

Issued shortly after the armistice, the Bishops' Program urged that the War Labor Board be retained as an instrument for securing a measure of industrial peace. Its principles, methods and results constituted, it was declared, "a definite and far-reaching gain for social justice." The Pastoral Letter insists especially upon industrial arbitration. "A dispute," it reads, 
"that cannot be adjusted by direct negotiation between the parties concerned should always be submitted to arbitration."

\section{Works Councils}

As a means of establishing greater peace between employers and employees the Pastoral Letter recommends that labor unions should be supplemented "by associations or conferences, composed jointly of employers and employees, which will place emphasis upon the common interests rather than the divergent aims of the two parties, upon coöperation rather than conflict." The common ground upon which they can unite is declared to be those matters of industrial management which directly concern the employee and about which he possesses helpful knowledge. 'The Bishops' Program brings forward the same recommendation. It says that "labor ought gradually to receive a greater representation in the industrial part of business management, the control of processes and machinery, nature of product; engagement and dismissal of employees; hours of work, rates of pay, bonuses, etc., welfare work; shop discipline; relations with trade unions." In effect both the Pastoral Letter and the Bishops' Program advocate that in addition to the influence which working people possess through collective bargaining, they should share in the industrial management. The Pastoral Letter says that this would benefit the workers, the employers, and the general public.

\section{Soctal Legislation}

While the Pastoral Letter includes legislation as one of the methods of righting social wrongs, it does not advocate any particular piece of legislation. The Bishops' Program, on the other hand, recommends a far-reaching program of social legislation, including minimum-wage laws, social insurance, federal employment bureaus, municipal housing, etc.

On the living-wage law it says that "the several states should enact laws providing for the establishment of wage rates that will be at least sufficient for the decent maintenance of a family, in the case of all male adults, and adequate to the decent individual support of female workers."

Ultimately the legal wage rate should be a "saving wage," and should allow for future contingencies. Meanwhile, social insurance should provide for illness, invalidity, unemployment and old age. To such an insurance fund the state should contribute very little, and that much only temporarily, and workingmen should contribute nothing unless they are making enough already to meet the present needs of a family. The fund should be raised by a levy on industry for "the industry in which a man is employed should provide him with all that is necessary to meet all the needs of his entire life."

\section{The Guild System}

The Pastoral Letter in its section on industrial relations does not mention, except by implication, socialism or common ownership. A short passage is all that is given to it in the Bishops' Program, where it says that socialism will probably never come, and if it does, it will mean bureaucracy, political tyranny, etc. Instead, both the Pastoral Letter and the Bishops' Program insist upon a sound and deep reform of private ownership along the lines of the guild system of the Middle Ages.

The heart of the recommendation, in the words of the Bishops' Program, is this: "The majority must somehow become owners, or at least in part, of the instruments of production." The ma- 
jority of the workers are not to remain "mere wage-earners." "To a great extent the abolition of the wage system" is involved and until this situation is reached we cannot "have a thoroughly efficient system of production, or an industrial and social order that will be secure from the danger of revolution."

The Pastoral Letter approaches the question from another angle to reach the same conclusion. It is seeking a remedy for the division of "society into two widely differing castes" of which one "holds power because it holds wealth" while the other is "the needy and powerless multitude." Following Pope Leo's recommendation and the spirit of the Church in building up the guilds of the Middle Ages, the Pastoral Letter says that the underlying principle of the economic arrangements of the Middle Ages " is of permanent application and is the only one that will give stability to industrial society." It says further that the underlying principle of the economicarrangements of the Middle Ages was that the persons who worked owned the lands and the tools with which they worked.

The Bishops' Program points out that the working people can be enabled to reach the stage of ownership through coöperative productive societies and copartnership arrangements. The Pastoral Letter does not indicate any specific method; it contents itself with urging that the desired changes be realized as rapidly as conditions will permit.

\section{Activities}

Labor matters are entrusted by the Welfare Council to its Social Action Department under the directorship of Rev. John A. Ryan, D.D. The work done is chiefly educational.

Three books have been published in the Social Action Series. The first is
The Church and Labor, by Dr. Ryan and Rev. Joseph Husslein, S.J., a volume consisting largely of documents issued by Popes, Bishops and the Hierarchy of various countries. In addition to an introduction which collects the teachings of the various doctrines into a synthesis, the pioneer work of Bishop Ketteler and Frederic Ozanam is described. The second is The Social Mission of Charity, by Rev. Wm. J. Kerby, Ph.D., an original work detailing the purpose and the meaning of charitable activities. The third, just published, is The State and the Church, by Dr. Ryan and Rev. Moorhouse F. X. Millar, S.J., which deals with the nature and purpose of political government and, therefore, includes a section on the relation of the state to industry.

Four pamphlets have also been issued, Capital and Labor-Methods of Harmony and Conciliation by Rev. John A. Ryan, Bolshevism in Russia and America by Rev. R. A. McGowan, A Cathechism of the Social Question by Revs. John A. Ryan, D.D., and R. A. McGowan, and Cardinal O'Connell's Pastoral on Religious Ideals in Industrial Relations.

Besides these publications, a weekly news service on current events in the world of labor is sent to Catholic papers, the labor news service and the general press services. Liberal use is made of the Bishops' Program, the Pastoral Letter and the encyclical of Pope Leo "On the Condition of Labor." An attempt is frequently made to make an appraisal of the effect of various events as they arise and the Bishops' Program, the Pastoral Letter and Pope Leo's encyclical are quoted in defense or in condemnation of proposals, facts, movements, etc., in the world of labor. A section of the N.C.W.C. Bulletin, a monthly magazine, is also edited by the Social Action 
Department, and space is given to general articles on labor and to news and comment on industrial relations.

A particular piece of work that went beyond the ordinary was the condemnation of the open shop drive in its infancy early in November 1920. This was before other organizations had come to the rescue of the working people and the labor unions in their resistance to wage cuts and the attacks upon their unions. A reply to the exposé, published in an obscure journal and distributed broadcast through the mails at great expense, brought further details from the Social Action Department of the real purpose behind all the propaganda about the freedom and Americanism of the open shop. A later statement was issued protesting against wage cuts as subversive of the principle of a living wage. Week by week, however, the attempt has been made to assist the working people in their struggles of the past two years in the various strikes and controversies that have arisen, and to point the way to the solution of the labor problem which Catholic social teaching indicates.

About thirty-five social study clubs were established last winter with the assistance of the Social Action Department. These study clubs meet weekly and discuss informally what the labor problem means, and how to solve it. They use as a text the Social Action Department's Catechism of the Social Question.

A lecture service on labor questions and social work and citizenship has been conducted for Catholic colleges and seminaries and Catholic clubs in secular schools. In addition, members of the Department are frequently called upon to address labor conventions, city clubs, chambers of commerce, social workers' conventions, public forums and conventions of coöperative organizations.

Besides giving publicity to the cooperative movement and whatever aid and comfort is at hand, a representative of the Department is on the Board of Directors of the Coöperative League of America, and contact is preserved with the All-American Coöperative Commission.

During the coal strike, in addition to measuring the coal industry by the Bishops' Program and the Pastoral Letter, a statement was issued jointly with the Federal Council of Churches urging the operators and miners to meet in conference, and calling for a permanent body to investigate the coal industry. Later, jointly with the same body, a conference was held with President Harding during which he was asked to call a conference of the operators and miners. A few weeks later, a committee consisting of representatives of the National Catholic Welfare Council, of the Federal Council of Churches and of the American Conference of Jewish Rabbis, presented another memorial on the same subject to President Harding. An early piece of work that was carried on with the Federal Council of Churches was the investigation of the Denver street-car strike at the request of a local commission of all the churches.

The aim throughout has been to make Catholic social teaching known and practiced. Since Catholic social teaching is distinctly favorable to the working people, the National Catholic Welfare Council is distinctly favorable to the working people. What it aims to do is to bring more justice and charity into industrial life, and help to build economic institutions that will take more into consideration the sacred rights and the no less sacred duties of human beings. 